\title{
Light: An Alternative Method for Physical Control of Postharvest Rotting Caused by Fungi of Citrus Fruit
}

\author{
İbrahim Kahramanoğlu $\mathbb{D}^{1},{ }^{1}$ Muhammad Farrukh Nisar (D), ${ }^{2,3}$ Chuying Chen ${ }^{2},{ }^{2}$ \\ Serhat Usanmaz, ${ }^{1}$ Jinyin Chen $\mathbb{D},,^{2,4}$ and Chunpeng Wan $\mathbb{D}^{2}$ \\ ${ }^{1}$ European University of Lefke, Gemikonagi, Northern Cyprus, Turkey \\ ${ }^{2}$ Jiangxi Key Laboratory for Postharvest Technology and Nondestructive Testing of Fruits \& Vegetables, \\ Collaborative Innovation Center of Postharvest Key Technology and Quality Safety of Fruits \& Vegetables in Jiangxi Province, \\ College of Agronomy, Jiangxi Agricultural University, Nanchang 330045, China \\ ${ }^{3}$ Key Laboratory of Crop Physiology, Ecology and Genetic Breeding, Ministry of Education, Jiangxi Agricultural University, \\ Nanchang, Jiangxi, China \\ ${ }^{4}$ College of Materials and Chemical Engineering, Pingxiang University, Pingxiang 337055, China
}

Correspondence should be addressed to Chunpeng Wan; chunpengwan@jxau.edu.cn

Received 7 May 2020; Revised 11 June 2020; Accepted 10 July 2020; Published 1 August 2020

Academic Editor: Flora V. Romeo

Copyright $\odot 2020$ İbrahim Kahramanoğlu et al. This is an open access article distributed under the Creative Commons Attribution License, which permits unrestricted use, distribution, and reproduction in any medium, provided the original work is properly cited.

\begin{abstract}
Solar light has fundamental roles in vast chemical, biochemical, and physical process in biosphere and hence been declared as "source of life." Solar light is further classified into a broad range of electromagnetic waves, and each region in the solar spectrum bears its unique actions in the universe or biosphere. Since centuries, solar light is believed as a potent source of killing pathogens causing postharvest losses on food products as well as human skin diseases. Citrus fruit crops are widely produced and consumed across the world, but due to their higher juicy contents, Penicillium italicum (blue mold) and Penicillium digitatum (green mold) make their entry to decay fruits and cause approximately $80 \%$ and $30 \%$ fruit losses, respectively. Agrochemicals or synthetic fungicides are highly efficient to control these postharvest fungal pathogens but have certain health concerns due to toxic environmental residues. Therefore, the scientific community is ever looking for some physical ways to eradicate such postharvest fungal pathogens and reduce the yield losses along with maintaining the public health concerns. This review article presents and discusses existing available information about the positive and negative impacts of different spectrums of solar light exposure on the postharvest storage of citrus fruits, especially to check citrus postharvest rotting caused by Penicillium italicum (blue mold) and Penicillium digitatum (green mold). Moreover, a special focus shall be paid to blue light (390-500 nm), which efficiently reduces the decay of fruits, while keeping the host tissues/cells healthy with no known cytotoxicity, killing the fungal pathogen probably by ferroptosis, but indepth knowledge is scanty. The study defines how to develop commercial applications of light in the postharvest citrus industry.
\end{abstract}

\section{Introduction}

Citrus (family, Rutaceae) fruits are famous all across the world and have a commercial production in over 137 countries [1]. The total production area of citrus (oranges, grapefruits, pomelos, lemons, limes, tangerines, mandarins, clementines, and satsumas) on the world was about 9.7 million ha, where about 138.5 million tones of fruits were harvested in 2018 [2]. The contribution of the citrus industry to the world economy is enormous, and it provides jobs to millions of people around the world in harvesting, handling, transportation, storage, and marketing operations. The importance of citrus fruit is attributed to its diversified use, which is widely consumed either as fresh fruit, as juice or in confectionaries. Citrus fruits have pleasant flavors, attractive colors, and aroma and are well-preferred by the consumers. It also has high nutritional concentration and health-promoting bioactive compounds, including ascorbic acid 
(vitamin C), phenolic acids, flavonoids, carotenoids, pectin, and other compounds $[3,4]$. Due to their higher water content and nutrient composition, citrus fruit is very susceptible to infection by microbial pathogens during the period between harvest, transportation, and consumption [5]. Postharvest decays of citrus fruit can also originate from latent infections occurring in the orchard such as black rot caused by Alternaria alternate pv. citri, brown rot caused by Phytophthora citrophthora, and anthracnose caused by Colletotrichum gloeosporioides [4]. In developing and nondeveloped countries, high losses occurred due to poor storing, inadequate transportation, handling, and postharvest storage $[6,7]$. Citrus fruits are highly susceptible to a variety of postharvest diseases causing huge losses during postharvest phase [8]. Postharvest losses, not only for citrus but also for all food products, are gaining more attention due to the global hunger [9], and prevention of postharvest losses is thought to be the common global goal of humanity for the issue of global achieving sustainable food security [10].

Most important postharvest losses of citrus, as of many other fruits, are caused by weight loss and pathogenic decay (mainly caused by Penicillium italicum Wehmer "blue mold" and $P$. digitatum Sacc. "green mold"). Total losses caused by these two pathogens were noted to reach up to $80 \%$ and $30 \%$, respectively [11]. Both of them are known to be reproduced asexually by airborne spores and generally infect the fruits through to wounds. The spores are greatly produced by rotten fruits and easily contaminate the surrounding fruits. The severity of the pathogen damages mainly depends on the amount of spores and optimal temperature which is about $20-25^{\circ} \mathrm{C}[12]$.

Chemical fungicides are the primary preferences of growers/packing houses for the postharvest control of pathogens [13]. However the excessive or misuse of agrochemicals was reported to result with resistant fungi strains which reduce the effectiveness of the fungicides [14] and associated with several environmental and health-base issues [15]. Furthermore, agrochemical residues in food have been the topic of numerous public discussions in the world [16], which reduced the acceptability of chemicals in agriculture [17]. Moreover, supermarkets, citrus export companies, and countries began to adopt strict policies regarding pesticide residues [4]. Therefore, an important need arises to develop alternative postharvest decay control measures to agrochemicals and it has been an important topic for the scientific world [18]. Since then, numerous studies have been conducted to develop/investigate alternatives to the chemical fungicides for the control of blue and green molds and came up with promising results where they suggested that biocontrol agents, i.e., some strains of yeasts and bacteria [19], hot water treatment (HWT) [20], hot air treatment [21], salts [22], second metabolites of plants [23], plant extracts [24], nanomaterials [25] and light irradiation [26] are effective.

The sun's light is accepted by scientists as the source of life on the earth. The light radiation of the sun flows into space, warms our planet, and has fundamental roles in many chemical, biochemical, and physical processes, including the most known photosynthesis. It also possesses an important role in water and nutrient cycles which are the basis of ecological balance on the earth [27]. Based on the wellknown definition of Paracelsus, the "dose" is the determinant of toxicity, and it is obvious that the earth's position in the solar system is optimal for preventing us from burning but sustaining the life by supplying enough radiation. The entire range of the light is named as the electromagnetic spectrum which ranges from long radio waves to gamma $(\gamma)$ rays [28]. The energy and the wavelength are known to have a reverse relationship, where the energy increases while the wavelength decreases. The visible spectrum of the light by the human eye makes up only a small fraction. The right side of the visible spectrum is generally known as nondangerous due to its low energy, where the left side of the visible spectrum (ultraviolet "UV" rays, X-rays, and gamma rays) is classified as harmful to many living organisms, due to their extremely high energies. However, most of the spectrums are absorbed by the atmosphere (primarily $\mathrm{CO}_{2}, \mathrm{H}_{2} \mathrm{O}$, and $\mathrm{O}_{3}$ ) with the exceptions of visible light, microwaves, and radio light, as well as a little of infrared and ultraviolet light [27].

The role of different spectrums of light in food preservation has been well studied and reported. Here, an important technology comes to forefront importance with the name of light-emitting diode (LED). It is a semiconductor diode capable of producing light. The LED technology is capable of producing monochromatic light, consisting of a narrow bandwidth of wavelengths. Thus, there are UV LEDs, IR LEDs, and LED blue lights available in food preservation technologies [29]. The efficacy of irradiation on the control of pathogens is reported to be mainly influenced by its type, penetration ability, and duration exposed [30]. The types of irradiation can be grouped into two categories as nonionizing irradiations (UV-C, UV-B, UV-A, and blue light) and ionizing irradiations (gamma $(\gamma)$ and $\mathrm{X}$-rays). Previous studies suggested that the mechanism of action varies depending upon the type of irradiation and fresh product, and the general mechanisms are as follows: inhibition of spore germination, increase in PAL activity and cell wall thickness, production of reactive oxygen species (ROS) in fungal cells, and enhancement of phytoalexin synthesis [26].

Light irradiation has different roles in plant and fruit bodies. Herein, it is necessary to mention about photooxidative stress/damage. Molecular oxygen in the living cells is known to be relatively unreactive in its ground state form. However, environmental stress conditions such as drought, ozone, salinity, cold, heat, changes in atmospheric composition, and light irradiation may cause a rise to various toxic reactive forms, called free radicals. Generally, the reactive oxygen species (ROS) result by transfer of one, two, or three electrons to molecular oxygen $\left(\mathrm{O}_{2}\right)$ to form superoxide radical $\left(\mathrm{O}^{2 \bullet-}\right)$, hydrogen peroxide $\left(\mathrm{H}_{2} \mathrm{O}_{2}\right)$, or hydroxyl radical $\left({ }^{\bullet} \mathrm{OH}\right)$, respectively. ROS are normally produced in every aerobic organism as by-products of several metabolic pathways (i.e., photosynthesis, respiration, and photorespiration). ROS play a significant role in plant and fruit growth, development, and homeostasis at normal concentrations by signalling mediators for different cellular responses. However, a rapid rise in the ROS concentration due to stress conditions in living cells may cause damage to 


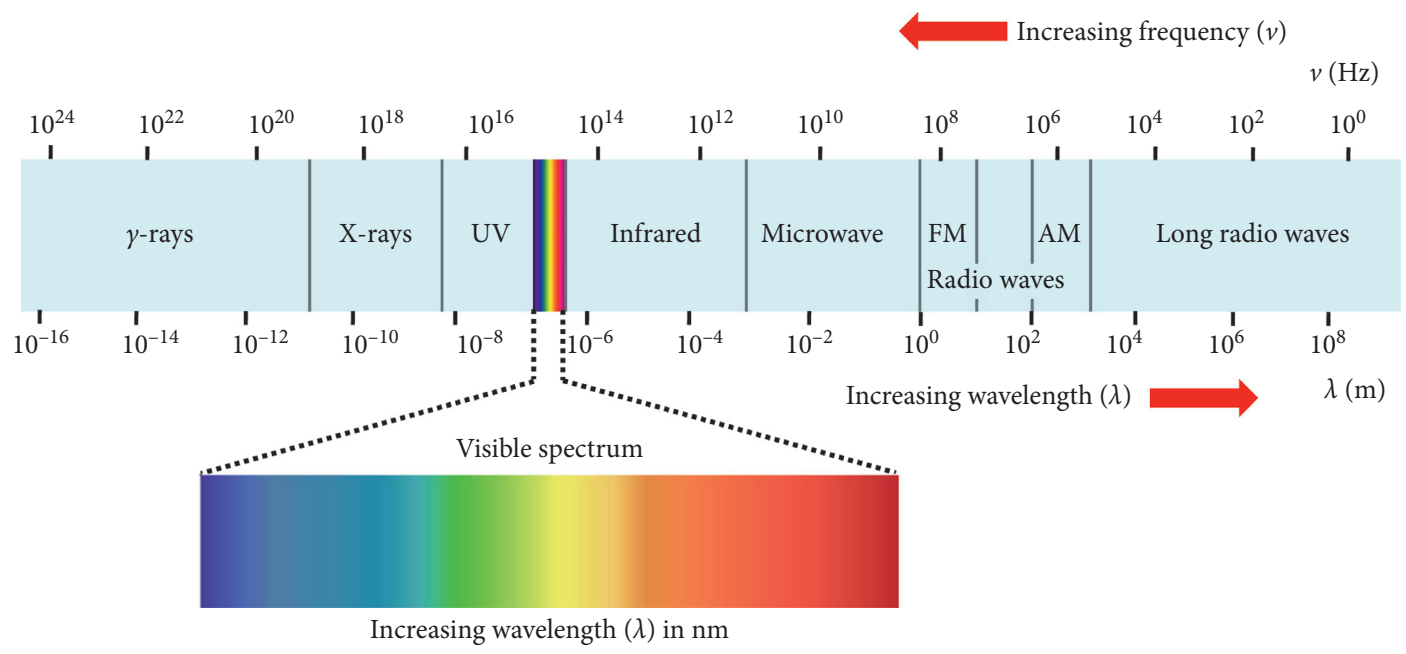

Figure 1: The solar electromagnetic spectrum.

proteins, lipids, carbohydrates, and DNA, which results in oxidative stress in the cells [31]. Among these stress conditions, light irradiation induced ROS generation is known as photooxidative stress/damage in plants [32]. Living plant cells have several defence mechanisms including nonenzymatic and enzymatic antioxidants to either prevent the formation or eliminate the ROS. The nonenzymatic antioxidant defence mechanism includes ascorbic acid, vitamin A, vitamin E, ascorbate, carotenoids, and phenols which directly react with ROS. Moreover, the enzymatic defence mechanism includes some enzymes, i.e., superoxide dismutase (SOD), catalase (CAT), ascorbate peroxidase (APX), peroxidase (POD), and glutathione reductase (GR), which help in scavenging specific reactive oxygen species. Oxidative stress induced by light irradiation may stimulate the biosynthesis of those enzymatic and nonenzymatic components as a defence mechanism in plants and in harvest fresh product $[31,33,34]$.

Plants and harvested fresh fruits and vegetables also produce $\mathrm{ROS}$ as a defence mechanism when they are attacked by pathogens as a result of the activation of defence genes. Those antimicrobial compounds have low molecular weight and are named as phytoalexins. They have special roles in the defence system and enable plants/foods to control pathogens [35]. Phytoalexin synthesis can be modified with the effect of several factors, such as light irradiation, temperature, and humidity [36, 37]. Phytoalexins are known to inhibit the mycelial growth of fungi, rupture the plasma membrane, and inhibit the elongation of the germ tube $[38,39]$. One of the most important phytoalexins which is produced by the citrus species as a defence mechanism to pathogens is the scoparone (6,7-dimethoxy coumarin). It was firstly noted by Riov [40] that the accumulation of scopoletin, scopolin, and scoparone increases in the grapefruit peel under irradiated conditions (at 1-4kGy). Researchers noted that the nonirradiated fruits do not have scoparone, whereas scopoletin and scopolin are found in very low concentrations. Scoparone was then isolated from the peel of grapefruit which infected with P. italicum [41]. 4(3-Methyl-2-butenoxy) isonitroso acetophenone is another irradiation-induced stress metabolite with antifungal activity noted from the irradiated peel of "Valencia" orange fruits [42].

In line with this information, this review attempts to discuss the possible mechanism of each irradiation type on the control of postharvest citrus rotting caused by Penicillium italicum (blue mold) and Penicillium digitatum (green mold).

\section{Nonionizing Irradiations}

Nonionizing radiation refers to any types of irradiation in the electromagnetic spectrum (from ultraviolet "including" to the right in Figure 1) where they do not carry sufficient energy to cause ionization, removing electrons from atoms and molecules. Among the nonionizing irradiations, ultraviolet (UV: $100-400 \mathrm{~nm}$ ) irradiation and blue light (400-500 nm) were previously tested for postharvest control of pathogens. The FDA (the US Food and Drug Administration) has given permission to the application of UV for pathogen control in food storage [43]. The UV is divided into 3 groups as follows: UV-C (100-280 nm), UV-B $(280-315 \mathrm{~nm})$, and UV-A $(315-400 \mathrm{~nm})$. The treatment of UV generally took place by placing the fruits underneath the UV lamps. The duration of UV treatment may vary from a few seconds to a few hours, and this is the main determinant affecting the impact of treatment. The UV irradiation was known to sense by fruit tissues through photoreceptors, and it regulates some metabolic reactions in cells [44]. The positive effects of UV irradiation types were separately discussed in following sections.

2.1. UV-CIrradiation. Among the types of UV, the extensive works were previously conducted on UV-C and numerous studies reported success on the control of postharvest rotting caused by $P$. digitatum and $P$. italicum, whereas high intensities were reported to cause significant damages on the citrus fruit flavedo [45] (Table 1.). Gündüz and Pazır [48] carried out in vivo research, after an in vitro test, and studied the effects of UV-C treatment on the control of $P$. digitatum 
TABLE 1: Effects of UV-C irradiation on the postharvest rotting caused by P. italicum and P. digitatum.

\begin{tabular}{|c|c|c|c|c|}
\hline Citrus species & Fungi species & Treatment/intensity & Mechanism of action & References \\
\hline Orange & P. digitatum & $\begin{array}{l}\text { Fruits were placed } 65 \mathrm{~cm} \text { below the UV-C } \\
\text { source }\left(0.1 \mathrm{~W} \cdot \mathrm{m}^{2}\right)\end{array}$ & $\begin{array}{l}\text { Reduced growth of pathogen, attributed to } \\
\text { increase in flavonoids content }\end{array}$ & {$[46]$} \\
\hline Orange & P. digitatum & $\begin{array}{l}20 \mathrm{~cm} \text { above the fruits with } 3.6 \mathrm{~W} \text { and } \\
1.5 \mathrm{KJ} \cdot \mathrm{m}^{2}\end{array}$ & $\begin{array}{l}\text { Reduction in fungi population which was } \\
\text { attributed to the accumulation of } \\
\text { phytoalexin scoparone in the fruits }\end{array}$ & {$[47]$} \\
\hline Orange & $\begin{array}{l}P . \text { italicum } \\
\text { and } P \text {. } \\
\text { digitatum }\end{array}$ & Irradiation $\left(7.92 \mathrm{kJm}^{2}\right)$ & Spore inactivation on the fruit surface & {$[48]$} \\
\hline Orange & $\begin{array}{l}P . \text { italicum } \\
\text { and } P \text {. } \\
\text { digitatum }\end{array}$ & 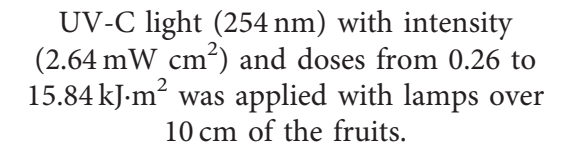 & $\begin{array}{l}\text { Reduction in the fungi spores by the } \\
\text { germicidal effects of UV-C }\end{array}$ & {$[49]$} \\
\hline $\begin{array}{l}\text { In vitro at potato } \\
\text { dextrose agar } \\
\text { (PDA) }\end{array}$ & P. digitatum & $\begin{array}{c}\text { Complete inhibition from } 396 \mathrm{mws} \cdot \mathrm{cm}^{2} \\
\text { UV-C exposure }\end{array}$ & $\begin{array}{c}\text { Reported to have some type of a hedonal } \\
\text { impact on reducing the reproduction of } P \text {. } \\
\text { digitatum }\end{array}$ & {$[50]$} \\
\hline Grapefruit & P. digitatum & $\begin{array}{l}\text { Fruits were placed } 10 \mathrm{~cm} \text { away from the } \\
\mathrm{UV}-\mathrm{C} 254 \mathrm{~nm} \text { lamps with } 2.7 \mathrm{~W} \cdot \mathrm{m}^{2} \text { fluency } \\
\text { rate }\end{array}$ & $\begin{array}{c}\text { Enhanced resistance to } P \text {. digitatum which } \\
\text { was attributed to the accumulation of a } \\
\text { chitinase and 1,3-endoglucanase proteins at } \\
\text { the fruits' peel }\end{array}$ & {$[51]$} \\
\hline $\begin{array}{l}\text { Grapefruit and } \\
\text { tangerine }\end{array}$ & P. digitutum & UV-C dose of $1.3 \mathrm{~kJ} \cdot \mathrm{m}^{2} \mathrm{~d}$ & $\begin{array}{l}\text { Reducing the incidence of pathogen by } \\
\text { induced resistance at the fruits }\end{array}$ & {$[52]$} \\
\hline Tangerines & P. digitatum & $\begin{array}{c}\mathrm{UV}-\mathrm{C} \text { dose of } 1.3 \mathrm{~kJ} \cdot \mathrm{m}^{2} \text { for } 1.75 \mathrm{~min} \text { (fruits } \\
\text { were placed } 10 \mathrm{~cm} \text { away and rotated } 4 \\
\text { times) }\end{array}$ & $\begin{array}{l}\text { Reducing the incidence of pathogen due to } \\
\text { the control of latent infection }\end{array}$ & {$[53]$} \\
\hline Tangerines & P. digitatum & $\mathrm{UV}-\mathrm{C}$ dose of $1.3 \mathrm{~kJ} \cdot \mathrm{m}^{2}$ for $1.75 \mathrm{~min}$ & $\begin{array}{l}\text { Reducing the incidence of pathogen by } \\
\text { induced host resistance to postharvest decay }\end{array}$ & {$[54]$} \\
\hline Kumquats & P. digitatum & $\mathrm{UV}-\mathrm{C}$ at $0.2 \times 103$ to $1.5 \times 103 \mathrm{~J} \cdot \mathrm{m}^{2}$ & $\begin{array}{c}\text { Induction of resistance to } P \text {. digitatum was } \\
\text { previously attributed to phytoalexin and } \\
\text { scoparone accumulation }\end{array}$ & {$[45]$} \\
\hline
\end{tabular}

and $P$. italicum spores inoculated at the orange fruits. Researchers placed oranges $10 \mathrm{~cm}$ below the UV-C lamps and treated for $5 \mathrm{~min}\left(7.92 \mathrm{~kJ} \cdot \mathrm{m}^{-2}\right)$. Authors reported that the UV-C treatment is effective for reducing the percentages of infected fruits to about 3 -fold as compared to control fruits, but they also suggested that the complete inactivation was not successful due to the low penetration ability of UV-C light. In a closely related previous study by Gündüz et al. [49], UV-C $\left(0.26-15.84 \mathrm{~kJ} \cdot \mathrm{m}^{-2}\right)$ was applied to the navel oranges with lamps located $10 \mathrm{~cm}$ upward of the fruits (Table 1). Prior to UV-C application (254 nm with an intensity of $2.64 \mathrm{~mW} \cdot \mathrm{cm}^{-2}$ ), spores of the two causes of citrus rotting, $P$. digitatum and $P$. italicum, were inoculated to the fruits with a rate of 4.00 and $4.50 \log$ cfu fruit $^{-1}$, respectively. According to the results of the mentioned study, the $3.17 \mathrm{~kJ} \cdot \mathrm{m}^{-2} \mathrm{UV}-\mathrm{C}$ dose was found to provide better control of $P$. digitatum and of $4.75 \mathrm{~kJ} \cdot \mathrm{m}^{-2} \mathrm{UV}-\mathrm{C}$ dose was noted to provide maximum control of $P$. italicum. The UV-C treatment was noted to provide significant control over two fungi for both spot and wound inoculation methods. The effects of different doses of UV-C treatment on the $P$. digitatum at orange fruits were previously studied by Fernandez and Hall [50]. UV-C (254 nm with an output of $0.66 \mathrm{mws} \cdot \mathrm{cm}^{-2}$ ) lamps were used in their study with exposure times varying from $10 \mathrm{~s}$ to $10 \mathrm{~min}$. As a result, they reported that the complete inhibition of $P$. digitatum was only from $396 \mathrm{Mws} \cdot \mathrm{cm}^{-2} \mathrm{UV}-\mathrm{C}$ exposure, where almost complete, partial, slight, and no visible inhibition of myclial growth was noted from $198,99,39.6$, and $26.4 \mathrm{Mws} \cdot \mathrm{cm}^{-2}$ UV-C exposure, respectively. In a more detailed study about the effects of different doses of UV-C on the inhibition of $P$. digitatum, valuable results were noted for science by Trivittayasil et al. [55]. It was suggested by the researchers that the $P$. digitatum has a resistance to low doses of UV-C application and the survival curve of the pathogen is nearly linear (adjusted $R^{2}=0.95$ ). Thus, suggesting that the increase in the dose of UV-C provides better inhibition of the pathogen, as suggested by the Fernandez and Hall [50]. Rather than oranges, some studies were also conducted with tangerines. In one of these studies, Stevens et al. [53] tested the influence of UV-C $(254 \mathrm{~nm})$ alone or in combination with Debaryomyces hansenii on the control of P. digitatum. In this study, UV-C was applied at a dose of $1.3 \mathrm{~kJ} \cdot \mathrm{m}^{-2}$ for $1.75 \mathrm{~min}$, and during treatments, fruits were placed $10 \mathrm{~cm}$ away and rotated 4 times. Researchers reported that the UV$\mathrm{C}$ treatment alone reduced the incidence of $P$. digitatum, but higher influence was reported for the combination of UV-C and D. hansenii. Similar results were also reported for both tangerines and grapefruits by Stevens et al. [52].

In an early study by Stevens et al. [54], the same dose of UV-C (254 nm at $\left.1.3 \mathrm{~kJ} \cdot \mathrm{m}^{-2}\right)$ was applied through the stem end in a stationary position without rotation and it was compared with the conventional procedure where the fruits were rotated 4 times. Furthermore, researchers noted that the treatment through the stem end provides better control of $P$. digitatum as compared with the rotation method. 
Similar result for $P$. digitatum was previously reported by Arcas et al. [46], and their study went deeper to determine the changes in flavonoid levels. In their research studies, they placed fruits $65 \mathrm{~cm}$ below the UV-C source $\left(0.1 \mathrm{~W} \cdot \mathrm{m}^{-2}\right)$. Researchers suggested that the UV-C treatment reduced the naringin content while promoted an increase in tangeretin contents. In a different study by D'hallewin et al. [47], the UV-C $(254 \mathrm{~nm})$ irradiation treatment $(20 \mathrm{~cm}$ above the fruits with $3.6 \mathrm{~W}$ and $1.5 \mathrm{~kJ} \cdot \mathrm{m}^{-2}$ ) was tested against $P$. digitatum at orange fruits. Approximately $75 \%$ reduction was noted for the fungi population and this success was associated with the phytoalexin scoparone accumulation in the fruits. Induction of resistance to $P$. digitatum was previously attributed to phytoalexin and scoparone accumulation in kumquat fruits too [45].

In a different study, Papoutsis et al. [56] tested the effects of UV-C application $\left(4,19,80\right.$, and $\left.185 \mathrm{~kJ} \cdot \mathrm{m}^{-2}\right)$ on the total phenolic content and antioxidant activity of dried powders of lemon pomace. No specific tests were performed on the growth and development of blue or green mold, but the results were meaningful in which the phenolics and antioxidant activities are known to enhance fruits resistance to pathogens [46]. According to the results of Papoutsis et al. [56], UV-C treatment was found to significantly affect the antioxidant activity, phenolic content, and flavonoid concentration of the dried melon pomace powders. The changes in the phenolic contents and flavonoid contents were found to be differently influenced by the UV-C doses, where the highest phenolic content was recorded from $19 \mathrm{~kJ} \cdot \mathrm{m}^{-2} \mathrm{UV}-\mathrm{C}$ irradiation and the highest flavonoid content was noted from $180 \mathrm{~kJ} \cdot \mathrm{m}^{-2} \mathrm{UV}-\mathrm{C}$ irradiation treatments. The results of this study highlight the importance of dose and imply that specific studies are required for maximum control of pathogens on different fruits. In an earlier study by Porat et al. [51], it was also suggested that the UV-C application $\left(254 \mathrm{~nm}\right.$ and $2.7 \mathrm{~W} \cdot \mathrm{m}^{-2}$ fluency rate) enhanced the resistance of grapefruits against $P$. digitatum and this was attributed to be a result of the accumulation of a $25 \mathrm{kDa}$ chitinase and $39 \mathrm{kDa} 1,3$-endoglucanase proteins at the fruits' peel. Numerous studies have been conducted to identify the key factors and genome sequencing of some important flavonoid biosynthesis in different fruits $[57,58]$. These studies showed that the $R_{2} R_{3}$ MYB transcription factors directly influence the expression of genes related with the flavonoid biosynthesis $[59,60]$. Studies with fruits other than citrus, i.e., apple, strawberry, grape, and litchi, reported that $R_{2} R_{3}$ MYB transcription factors are inducible by light [61-64]. Moreover, it is well known that the biosynthesis of flavonoids is an important tool for the control of citrus rotting caused by $P$. digitatum and $P$. italicum [65].

2.2. UV-B Irradiation. Similar to the UV-C light, there are numerous studies in the published literature about the antifungal activities of UV-B, in which as a general, UV-B irradiation was reported to be less harmful for the fruits and less effective [66]. In a previous study by Ruiz et al. [67], the UV-B irradiation was reported to induce metabolic changes in the lemon fruit peel which then suggested contributing fruit protection against $P$. digitatum (Table 2.). The UV-B treatment was found to change the respiratory profiles and increased the concentration of the phenolic compounds (flavones, flavonols, and anthocyanins). Thus, the antioxidant activity of the lemon fruits was also increased. In another study by Ruiz et al. [44], it was also noted that the UV-B treatment increases the ROS and membrane permeability of the lemon fruits. The UV-B exposure was also found to cause changes in the soluble carbohydrate metabolism and secondary metabolite accumulation of lemon fruits. It was suggested that the concentration of the secondary metabolites depends on the dose and duration of the UV-B, and the durations over $3 \mathrm{~min}$ $\left(0.43 \mathrm{Wm}^{-2}=22 \mathrm{kJm}^{-2} \cdot \mathrm{d}^{-1} \mathrm{UV}-\mathrm{BBE}\right)$ were noted to not cause any significant changes in the concentration of secondary metabolites. By contrast, the soluble sugars' concentration accumulation in the peel was found to increase with the durations over $3 \mathrm{~min}$ [69]. This result is in agreement with the notes discussed above for the UV-C and findings of Trivittayasil et al. [55] and Fernandez and Hall [50], where they reported that the intensity and duration of irradiation are highly important for the success of the treatment. Successful results for UV-B were also noted for mandarins. In one of these studies by Yamaga et al. [68], it was note that the UV-B $\left(15,30,60\right.$, and $\left.120 \mathrm{~kJ} \cdot \mathrm{m}^{-2}\right)$ treatment significantly reduces the germination of $P$. italicum spores on the "satsuma" mandarins.

2.3. $U V-A$ Irradiation. The UV-A photons in the UV spectrum have less energy as compared with UV-C and UV$\mathrm{B}$, but they still have energy which can be absorbed by biological molecules and cause biochemical changes in the living tissues (Table 3 ). In a previous study, two phototoxins were reported to be activated by UV-A $(334 \mathrm{~nm})$, the a-terthienyl (a-T), and 8-methoxypsoralen (8-MOP), and these were noted to be effective in inactivation of some fungi, i.e., $P$. italicum [70]. It has been reported that harmol (1methyl-9H-pyrido[3,4-b]indol-7-ol) is an active $\beta$-carboline against $P$. digitatum [72], and the UV-A treatment (at $365 \mathrm{~nm}$ and $8 \mathrm{~W} \cdot \mathrm{m}^{-2}$ ) was then reported to improve the harmol activity and improve antimicrobial activity [71]. Due to the low energy charge of UV-A, as compared with UV-B and UV-C, the studies are limited with UV-A.

2.4. Blue Light. As compared with the UV irradiation, blue light is a part of the visible spectrum and is known to be normally absorbed by some plant tissues and to have roles in some metabolic reactions in the living tissues [73]. Blue light (390-500 nm) is reported to reduce decay of foods caused by fungal pathogens $P$. digitatum and $P$. italicum [74-76] (Table 4.) and promote the growth of plants, and its receptors participate in pathogenesis response signalling [79]. Blue light activates endogenous photoactive porphyrins within the bacterial or fungal cells [80]. It was noted that the blue light treatment $(450 \mathrm{~nm}$ at quantum fluxes between 60 and $630 \mu \mathrm{mol} \cdot \mathrm{m}^{-2} \cdot \mathrm{s}^{-1}$ ) causes an increase in scoparone concentration at the flavedo of sweet oranges and this improves the resistance of fruits to the $P$. digitatum [75]. 
TABLE 2: Effects of UV-B irradiation on the postharvest rotting caused by $P$. italicum and P. digitatum.

\begin{tabular}{|c|c|c|c|c|}
\hline $\begin{array}{l}\text { Citrus } \\
\text { species }\end{array}$ & $\begin{array}{l}\text { Fungi } \\
\text { species }\end{array}$ & Treatment/intensity & Mechanism of action & References \\
\hline Lemon & $\begin{array}{c}P . \\
\text { digitatum }\end{array}$ & $\begin{array}{c}\text { UV-B }\left(22,000 \mathrm{~J} \cdot \mathrm{m}^{-2} \cdot \mathrm{d}^{-1}\right) \text { lamps placed } 50 \mathrm{~cm} \\
\text { above the fruit }\end{array}$ & $\begin{array}{l}\text { Increase in cell wall thickness and concentration of } \\
\text { phenolics in the flavedo }\end{array}$ & {$[67]$} \\
\hline Lemon & $\begin{array}{l}P . \\
\text { digitatum }\end{array}$ & $\begin{array}{c}\text { UV-B }\left(22,000 \mathrm{~J} \cdot \mathrm{m}^{-2} \cdot \mathrm{d}^{-1}\right) \text { lamps placed } 50 \mathrm{~cm} \\
\text { above the fruit }\end{array}$ & $\begin{array}{l}\text { Increase in ROS and membrane permeability, which } \\
\text { results in improved antifungal activity }\end{array}$ & {$[44]$} \\
\hline Mandarin & P. italicum & $\begin{array}{l}\text { In in vitro studies, fruits were placed } 15 \mathrm{~cm} \\
\text { below UV-B lamps at } 15,30,60 \text {, and } 120 \mathrm{~kJ} \cdot \mathrm{m}^{2}\end{array}$ & $\begin{array}{l}\text { Inhibit the germination of fungi spores by directly } \\
\text { inactivating fungi and inducing an antifungal } \\
\text { response in fruits }\end{array}$ & {$[68]$} \\
\hline
\end{tabular}

TABle 3: Effects of UV-A irradiation on the postharvest rotting caused by P. italicum and P. digitatum.

\begin{tabular}{|c|c|c|c|c|}
\hline $\begin{array}{l}\text { Citrus } \\
\text { species }\end{array}$ & $\begin{array}{l}\text { Fungal } \\
\text { species }\end{array}$ & Treatment/intensity & Mechanism of action & References \\
\hline $\begin{array}{l}\text { In vitro at } \\
\text { PDA }\end{array}$ & P. italicum & $\begin{array}{l}\text { At a fluence rate of } \\
40-43 \mathrm{~J} \cdot \mathrm{m}^{-2} \cdot \mathrm{sec}^{-1}\end{array}$ & $\begin{array}{l}\text { Inactivation of some fungi which associated with the activation of two } \\
\text { phototoxins: the a-terthienyl (a-T) and 8-methoxypsoralen (8-MOP) }\end{array}$ & {$[70]$} \\
\hline $\begin{array}{l}\text { In vitro at } \\
\text { PDA }\end{array}$ & P. italicum & $\begin{array}{l}\text { Irradiation at } 365 \mathrm{~nm} \text { and } \\
\qquad 8 \mathrm{~W} \cdot \mathrm{m}^{-2}\end{array}$ & $\begin{array}{c}\text { Improvement in antimicrobial activity associated with increasing } \\
\text { harmol activity }\end{array}$ & {$[71]$} \\
\hline
\end{tabular}

TABLE 4: Effects of blue light irradiation on the postharvest rotting caused by P. italicum and P. digitatum.

\begin{tabular}{|c|c|c|c|c|}
\hline $\begin{array}{l}\text { Citrus } \\
\text { species }\end{array}$ & Fungi species & Treatment/intensity & Mechanism of action & References \\
\hline Orange & P. digitatum & $\begin{array}{l}\text { Blue light }(450 \mathrm{~nm}) \text { at quantum fluxes } \\
\text { between } 210 \text { and } 630 \mu \mathrm{molm}^{-2} \cdot \mathrm{s}^{-1}\end{array}$ & Increase in scoparone at fruit flavedo & {$[75]$} \\
\hline Mandarin & P. italicum & $\begin{array}{l}\text { Low-intensity blue LED }(465 \mathrm{~nm}) \text { with a } \\
\text { fluency of } 8 \mu \mathrm{mol} \cdot \mathrm{m}^{-2} \cdot \mathrm{s}^{-1}\end{array}$ & Suppression of fungi spore development & {$[76]$} \\
\hline Mandarin & $\begin{array}{l}\text { P. digitatum and } \\
\text { P. italicum }\end{array}$ & $\begin{array}{l}\text { Blue light at } 465 \mathrm{~nm} \text { with a photon flux of } \\
\qquad 80 \mu \mathrm{mol} \cdot \mathrm{m}^{-2} \cdot \mathrm{s}^{-1}\end{array}$ & $\begin{array}{l}\text { Prevention of microbial growth by increasing the } \\
\text { phytoalexin scoparone concentration }\end{array}$ & {$[77]$} \\
\hline Tangerine & P. digitatum & $\begin{array}{l}\text { Exposure of fruits to } 410-540 \mathrm{~nm} \text { blue } \\
\text { light at a fluency of } 40 \mu \mathrm{mol} \cdot \mathrm{m}^{-2} \cdot \mathrm{s}^{-1}\end{array}$ & $\begin{array}{l}\text { Induction in PLA2 gene expression which } \\
\text { resulted with reduced pathogen infection }\end{array}$ & {$[74]$} \\
\hline Tangerine & $\begin{array}{l}\text { P. digitatum and } \\
\text { P. italicum }\end{array}$ & $\begin{array}{l}\text { Blue light at the intensity of } \\
\qquad 40 \mu \mathrm{mol} \cdot \mathrm{m}^{-2} \cdot \mathrm{s}^{-1}\end{array}$ & $\begin{array}{l}\text { Induction of the octanal production and } \\
\text { reducing the activities of } P \text {. digitatum and } P \text {. } \\
\text { italicum }\end{array}$ & {$[78]$} \\
\hline
\end{tabular}

Antifungal effect of blue light irradiation ( $465 \mathrm{~nm}$ with a photon flux of $80 \mu \mathrm{mol} \cdot \mathrm{m}^{-2} \cdot \mathrm{s}^{-1}$ ) on the blue mold $(P$. italicum) and on satsuma mandarin fruits was also studied in both before and after fungal inoculation with no effect on the quality of fruits except for the citric acid concentration and moisture loss [81]. After the inoculation of the blue mold fungal pathogen, blue light reduces the sporulation and mycelium of $P$. italicum, while the 6-day irradiation period before the inoculation with pathogen showed less symptom development [81]. Another study claims that when blue light was exposed on the wounded satsuma mandarin fruits under storage conditions, it enhanced the production of phytoalexin scoparone and the blue light treated fruits had only $13.3 \%$ decayed fruits, where the nontreated fruits had $51.1 \%$ fruit decay caused by $P$. digitatum and P. italicum [77]. Direct exposure of blue light in in vitro conditions reduces the citrus decay rates caused by the $P$. italicum and $P$. citri. Blue light posed its effects mainly by changing citrus phospholipase A2 at transcriptional levels in citrus peels and hence lowered the decay process by decreasing the growth of $P$. digitatum $[74,82]$. The basic mechanism in this blue lightmediated fungal growth inhibition is the involvement of the lipid-derived pathways [82]. These studies further highlighted that blue light treatment has no effects on the rind color nor affects fruit quality parameters (soluble solid content, titratable acidity, specific gravity, and percentage of flesh) [77]. The citrus peels are rich in oils which contain lipid-derived constituents having antifungal activity [83]. Furthermore, it can easily be concluded from these studies that the blue light induces scoparone production, thus reducing the fruit decay caused by $P$. digitatum and P. italicum, but correct combination of intensity and duration is highly important for maximum control. In a different study with bayberries, the blue light treatment was noted to increase the anthocyanin concentration of the fruits [84], which might be a subject for the further studies with citrus fruits.

The blue light treatment (exposure of fruits to $410-540 \mathrm{~nm}$ blue light at a fluency of $40 \mu \mathrm{mol} \cdot \mathrm{m}^{-2} \cdot \mathrm{s}^{-1}$ ) was also noted to induce PLA2 gene expression in tangerine fruits which results with a reduced pathogen infection [74]. Exposure of fruits to low-intensity blue light (at $465 \mathrm{~nm}$ ) with a fluency of $8 \mu \mathrm{mol} \cdot \mathrm{m}^{-2} \cdot \mathrm{s}^{-1}$ was also noted to suppress the development of $P$. italicum spores at mandarin fruits [76]. Additionally, blue light at the intensity of $40 \mu \mathrm{mol} \cdot \mathrm{m}^{-2} \cdot \mathrm{s}^{-1}$ was found to reduce the cell wall digest enzyme activity of $P$. digitatum and $P$. italicum by inducing the octanal production in the tangerine fruits [78]. The findings of Liao et al. [78] are meaningful in which the 
TABLE 5: Effects of X-ray irradiation on the postharvest rotting caused by P. italicum and P. digitatum.

\begin{tabular}{lcccc}
\hline Citrus species & Fungi species & Treatment/intensity & Mechanism of action & References \\
\hline Mandarins & P. digitatum & Irradiation at 510 gray (Gy) & Delays the pathogen development & [88] \\
Mandarins & P. digitatum and P. italicum & Irradiation at 510 and 875 gray (Gy) & Inhibition of sporulation & [89] \\
\hline
\end{tabular}

increase in exposure duration to the blue light was found to have an increasing influence on the prevention of the citrus pathogens. Numerous previous studies suggested that the combination of more than one measure would provide higher efficacy for the food preservation, i.e., combination of modified atmosphere packaging and lemongrass oil [85]. Similarly, combination of blue light and erythrosine was found to provide better control of P. digitatum [86].

It is evident from this discussion that utilizing different approaches and techniques to eradicate the citrus blue mold and green mold is an important alternative for agrochemicals, and blue light has proven itself as one of the superior techniques to eradicate blue mold disease. Blue light is environmental friendly and cost effective, and it keeps the citrus skin color as well as fruit quality parameters. Moreover, with the passage of time, most pathogenic fungal strains may resist the traditional fungicides, and hence, demand for a superior and novel antifungal agent is demanding ever. To sum up, although the general mechanism of action of blue light treatment has not been fully understood up to now, there are two main hypotheses: one is the occurrence of endogenous photosensitizes within the pathogen cells which causes the inactivation of the pathogens and the other is the induction of secondary metabolites in fruit tissues which increases the resistance of the products to the pathogens $[75,87]$.

\section{Ionizing Irradiations}

Ionizing irradiation is a form of energy in the electromagnetic spectrum (from ultraviolet "excluding" to the left in Figure 1) where they carry sufficient energy to cause ionization, removing electrons from atoms and molecules, including air, water, and living tissues.

3.1. X-Ray Irradiation. $\mathrm{X}$-ray is one of the two ionizing irradiation forms of energy in the electromagnetic spectrum knowing to carry high energy. It was reported to be a promising technology for the disinfection of foods due to its antipathogenic characteristic (Table 5). X-ray irradiation was reported to disinfest Ceratitis capitata at the citrus fruits, and treating mandarins with $\mathrm{X}$-ray irradiation was found to not adversely affect the fruits' quality [90]. Although it has potential to prevent postharvest quality of foods, its acceptability by the consumers is in question due to its known ionizing characteristic [91]. Ionizing characteristics of X-ray irradiation cause oxidative stress in fruits, which can directly influence the bioactive compounds located in fruit tissues and could improve the resistance of those fruits to the pathogens [92]. The ionizing in the food products is thought to generate free radicals which may stimulate unwanted reactions in the living tissues [93]. However, there are some studies in the published literature which have been reported that the low doses of $\mathrm{X}$-rays are effective in controlling citrus rotting caused by blue and green mold [88, 89]. Moreover, the X-ray irradiation (510 and $875 \mathrm{~Gy}$ ) of mandarin fruits was found to increase phytoalexin scoparone and scopoletin concentrations in the fruit rind and reduce the $P$. digitatum infections [88]. Studies with the positive and negative effects of X-ray irradiation are limited with citrus fruits, and further studies are obligated to do any recommendations for their commercial use in the postharvest citrus handling.

3.2. Gamma $(\gamma)$-Ray Irradiation. Gamma $(\gamma)$-rays is the other type of irradiation in the electromagnetic spectrum which has the highest energy, and the low doses of $\gamma$-ray irradiation were also proven to regulate activities of some enzymes involved in scavenging of free radicals [94] and inhibit the development of fungal pathogens [30]. However, it was strongly highlighted by previous studies that the potential negative effects of $\gamma$-ray irradiated foods must be studied before their use [95]. In one of these studies, Jeong et al. [30] tested the in vitro activity of $\gamma$-rays ( $1.0 \mathrm{kGy})$ on the $P$. digitatum at "satsuma" mandarins and found out that it inhibits spore germination, mycelia growth of pathogen, and elongation of germ tube. However, the in vivo studies showed that this or higher doses cause severe damages on the fruit tissues. To eliminate the damages on the fruit tissue, researchers suggested that the incorporation of $\gamma$-rays at lower intensity $(0.4 \mathrm{kGy})$ with dichloro-striazinetrione $(\mathrm{NaDCC}, 10 \mathrm{ppm})$ provides similar effect on the pathogen and less damage on the fruit tissue. The impact of the combined treatment was suggested to be due to the synergistical damage on the pathogens' membrane. Moreover, these findings [30] are promising for future studies and development of appropriate technologies for the quality preservation of foods without significant damages on the fruit tissues, because it is a well-known phenomenon that higher doses of gamma radiation cause severe damages and mutation breeding in fruit tissues. In a study with Citrus sinensis, it was found that the doses more than 20 Gy $\gamma$-ray irradiation cause significant increase in peroxidase activity and decrease in chlorophyll content [96]. A study by Mahmoud et al. [97] noted that the application of gamma rays at doses of $0.4,0.8,1.6$, and $3.2 \mathrm{kGy}$ to the grapefruits helps to control postharvest decay. It was then noted by another study that the 150 and 200 krads gamma radiation suspends the spore germination of $P$. expansum [98]. However, even the less intensity of $\gamma$-ray irradiation was noted to cause significant changes in the phenolic compounds and enzymatic activities of citrus fruits. In one of these studies, $0.3 \mathrm{kGy} \gamma$-ray irradiation was noted to induce the biosynthesis of total phenolic compounds and also increase the phenylalanine ammonia-lyase (PAL) activity of Citrus clementina Hort. ex. Tanaka. Among the phenolic 


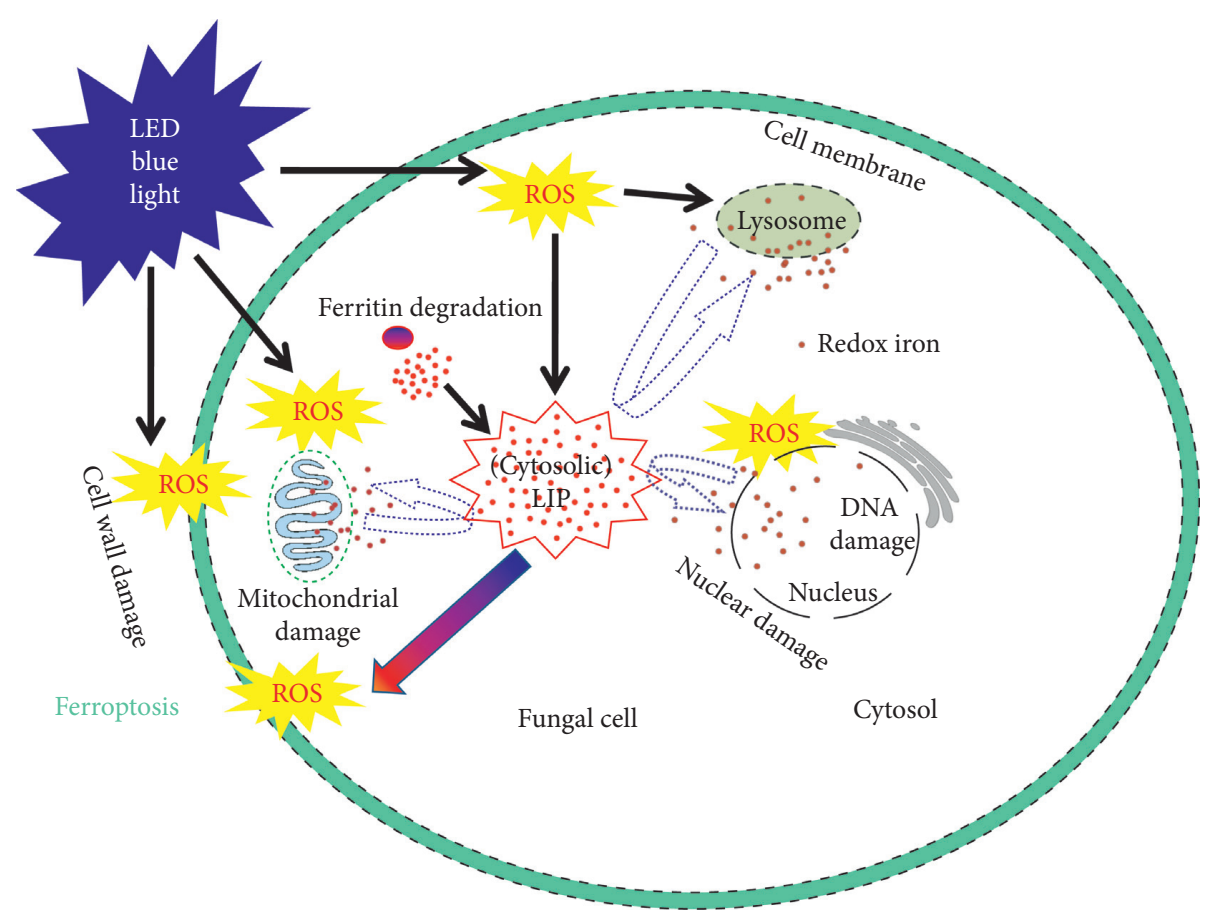

FIGURE 2: Blue light-induced ferroptosis in fungal cell.

compounds, the hesperidin, $p$-coumaric acid, and flavonoids were the compounds which highly influence by $\gamma$-ray irradiation [92]. Therefore, further studies are obligated to recommend any specific $\gamma$-ray irradiation treatment for the effective control of citrus rotting without any damages on the fruit quality and human health.

\section{Light Radiation and Ferroptosis in Fungal Cells}

Most studies concerning the application of either synthetic or the natural fungicides have been focused on the damage of the fungal hyphal cell walls leading to leakage of the cellular inclusions and finally the death of the fungal cells [99]. Recently, a phenomenon "ferroptosis" is introduced which is a regulated, nonapoptotic type of iron-dependent cell death reported in mammalian $[100,101]$ and plant cells $[102,103]$, and the whole phenomenon is portrayed in Figure 2. Herein, the light irradiation, especially the blue LED, induces the development of ROS in fungal cells, which then damages the cell wall and lysosome of the fungus and finally causes damage on the DNA. Ferroptotic cell death is distinct from apoptosis, necrosis, and autophagy [104]. Ferroptotic cell death requires iron and ROS accumulation [100, 101, 105]. Ferroptotic is initiated by inactivating glutathione-linked antioxidant defence and iron-mediated efflux of toxic lipid hydroperoxides along with numerous other reactive oxygen species (ROS) [106]. On the other hand, this can also be locked by iron chelators and antioxidants [101, 105]. Ferroptotic cells show different morphological and biochemical characteristics as compared with apoptosis. It includes cell rounding which is followed by rupturing of plasma membrane $[105,107]$. As a result of the accumulation of ROS, lipid peroxidation also occurs in ferroptotic cells [108]. It is further elucidated that free cellular iron along ROS and lipid hydroperoxides are directly involved in ferroptotic cell deaths [101]. At cellular level, iron behaves a strong redox catalyst [109], but it plays a great role in cell signalling and cell fate. In incompatible plant-pathogen interactions, a quick increase in ROS, iron, and $\alpha$-glutamylcysteine synthetase is thought as an important marker for ferroptotic cell death $[110,111]$. On the other hand, iron is essentially required by both the host and the pathogen for their normal growth, especially as a cofactor in certain metabolic processes. In many microbes, iron linked with hemin is needed for the growth and virulence in vitro. However, the role of porphyrin-associated iron and iron-withholding proteins in the citrus rind and P. italicum is not described yet. Moreover, how iron loads get activated in blue light exposed citrus rind and $P$. italicum hyphae and the activation of ferroptosis in fungal hyphae is not elucidated yet. However, recent scientific information suggests that fungi may undergo irondependent ferroptosis and are noted to be resulted by the loss of membrane integrity as a consequence of lipid peroxidation [112]. On the other hand, some studies suggest that the fungi may encode some inhibitors of programmed cell death (i.e., conserved BIR "baculovirus inhibitor of apoptosis repeat") [113]. Further studies are required to clarify the ferroptosis mechanism in fungus.

\section{Conclusions}

In conclusion, light irradiation (both nonionizing and ionizing irradiation) is a valuable physical technique for not only citrus but for other food products, by having a significant potential for controlling postharvest pathogens. 
Even though the full mechanism of the action is not well understood or varying among the specific varieties/conditions, it is well known that the light irradiation, in general, has two types of mechanisms for controlling the citrus pathogens. One of these mechanisms is the inducement of the biosynthesis of specific secondary plant metabolites, which improves the fruit/tissue resistance against pathogens, and the other mechanism is the direct prevention of the pathogen development and/or spore inactivation. Therefore, further studies about the improvement of the understanding about the mechanism could potentially lead to the development of commercial applications in postharvest handling. Moreover, UVA, UVB, and blue-light are involved in the production of the ROS, which possibly leads to the fungal cell deaths by ferroptosis, a novel mechanism which has hardly been studied before for fungal cells. The increments in the LED industry and technology have been a precious potential for the development and use of quick sanitation technologies in the citrus industry. Here, the UV LEDs, especially UV-C, are believed to be powerful tools for the citrus postharvest industry. Further studies, with more specified subjects about the negative influences on fruit quality, seem to be most important requirements for the development of large-scale technologies, which would have an important role in the improvement of consumer acceptability. Needless to say, optimum dosage (type, intensity, and duration) is also a must to determine for each variety. Finally, it is important to remind that the ionizing irradiations (X-rays and $\gamma$-rays) would have negative effects on citrus fruit quality and on human health. Therefore, special attention should be paid on this subject.

\section{Data Availability}

No data were used to support this study.

\section{Conflicts of Interest}

The authors declare that there are no conflicts of interest regarding the publication of this paper.

\section{Acknowledgments}

This research was funded by the Natural Science Foundation of Jiangxi Province (20181BCB24005).

\section{References}

[1] M. Ismail and J. Zhang, "Post-harvest citrus diseases and their control," Outlooks on Pest Management, vol. 15, no. 1, pp. 29-35, 2004.

[2] F. Fao, "Agriculture organization of the united nations," 2016.

[3] Z. Zou, W. Xi, Y. Hu, C. Nie, and Z. Zhou, "Antioxidant activity of Citrus fruits," Food Chemistry, vol. 196, pp. 885896, 2016.

[4] I. Talibi, H. Boubaker, E. Boudyach, and A. A. B. Aoumar, "Alternative methods for the control of postharvest citrus diseases," Journal of Applied Microbiology, vol. 117, no. 1, pp. 1-17, 2014.
[5] P. Tripathi and N. K. Dubey, "Exploitation of natural products as an alternative strategy to control postharvest fungal rotting of fruit and vegetables," Postharvest Biology and Technology, vol. 32, no. 3, pp. 235-245, 2004.

[6] M. Ladanyia and M. Ladaniya, Citrus Fruit: Biology, Technology and Evaluation, Academic Press, Cambridge, MA, USA, 2010.

[7] M. S. Ladaniya, "Commercial fresh citrus cultivars and producing countries," Citrus Fruit: Biology, Technology and Evaluation, Academic Press, Cambridge, MA, USA, pp. 13-65, 2008.

[8] E. Calavan, G. Carman, and L. Jeppson, The Citrus Industry, Centre for Agriculture and Bioscience International, Oakland, CA, USA, 1989.

[9] M. Shafiee-Jood and X. Cai, "Reducing food loss and waste to enhance food security and environmental sustainability," Environmental Science \& Technology, vol. 50, no. 16, pp. 8432-8443, 2016.

[10] B. Lipinski, C. Hanson, J. Lomax, L. Kitinoja, R. Waite, and T. Searchinger, Reducing Food Loss and Waste, pp. 1-40, World Resources Institute, Washington, DC, USA, 2013.

[11] M. El-Otmani, A. Ait-Oubahou, and L. Zacarías, "Citrus spp.: orange, Mandarin, tangerine, clementine, grapefruit, pomelo, lemon and lime," in Postharvest Biology and Technology of Tropical and Subtropical Fruits, pp. 437-516, Elsevier, Amsterdam, Netherlands, 2011.

[12] M. Kellerman, J. Joubert, A. Erasmus, and P. H. Fourie, “The effect of temperature, exposure time and $\mathrm{pH}$ on imazalil residue loading and green mould control on citrus through dip application," Postharvest Biology and Technology, vol. 121, pp. 159-164, 2016.

[13] Z. Berk, Citrus Fruit Processing, Academic Press, Cambridge, MA, USA, 2016.

[14] W. Hao, H. Li, M. Hu, L. Yang, and M. Rizwan-Ul-Haq, "Integrated control of citrus green and blue mold and sour rot by Bacillus amyloliquefaciens in combination with tea saponin," Postharvest Biology and Technology, vol. 59, no. 3, pp. 316-323, 2011.

[15] P. Nicolopoulou-Stamati, S. Maipas, C. Kotampasi, P. Stamatis, and L. Hens, "Chemical pesticides and human health: the urgent need for a new concept in agriculture," Frontiers in Public Health, vol. 4, p. 148, 2016.

[16] S. Koch, A. Epp, M. Lohmann, and G.-F. Böl, "Pesticide residues in food: attitudes, beliefs, and misconceptions among conventional and organic consumers," Journal of Food Protection, vol. 80, no. 12, pp. 2083-2089, 2017.

[17] R. R. Sharma, D. Singh, and R. Singh, "Biological control of postharvest diseases of fruits and vegetables by microbial antagonists: a review," Biological Control, vol. 50, no. 3, pp. 205-221, 2009.

[18] L. Palou, J. L. Smilanick, and S. Droby, "Alternatives to conventional fungicides for the control of citrus postharvest green and blue moulds," Stewart Postharvest Review, vol. 4, no. 2, pp. 1-16, 2008.

[19] J. M. Bazioli, J. R. Belinato, J. H. Costa et al., "Biological control of citrus postharvest phytopathogens," Toxins, vol. 11, no. 8, p. 460, 2019.

[20] İ. Kahramanoğlu, C. Chen, Y. Chen, J. Chen, Z. Gan, and C. Wan, "Improving storability of "nanfeng" mandarins by treating with postharvest hot water dipping," Journal of Food Quality, vol. 2020, Article ID 8524952, 12 pages, 2020.

[21] C. Wan, İ. Kahramanoğlu, J. Chen, Z. Gan, and C. Chen, "Effects of hot air treatments on postharvest storage of newhall navel orange," Plants, vol. 9, no. 2, p. 170, 2020. 
[22] J. L. Smilanick, M. F. Mansour, F. M. Gabler, and D. Sorenson, "Control of citrus postharvest green mold and sour rot by potassium sorbate combined with heat and fungicides," Postharvest Biology and Technology, vol. 47, no. 2, pp. 226-238, 2008.

[23] C. Chen, N. Cai, J. Chen, and C. Wan, "UHPLC-Q-TOF/MSbased metabolomics approach reveals the antifungal potential of pinocembroside against citrus green mold phytopathogen," Plants, vol. 9, no. 1, p. 17, 2020.

[24] J. Chen, Y. Shen, C. Chen, and C. Wan, "Inhibition of key citrus postharvest fungal strains by plant extracts in vitro and in vivo: a review," Plants, vol. 8, no. 2, p. 26, 2019.

[25] S. R. Roberto, K. Youssef, A. F. Hashim, and A. Ippolito, "Nanomaterials as alternative control means against postharvest diseases in fruit crops," Nanomaterials, vol. 9, no. 12, p. 1752, 2019.

[26] K. Papoutsis, M. M. Mathioudakis, J. H. Hasperué, and V. Ziogas, "Non-chemical treatments for preventing the postharvest fungal rotting of citrus caused by Penicillium digitatum (green mold) and Penicillium italicum (blue mold)," Trends in Food Science \& Technology, vol. 86, pp. 479-491, 2019.

[27] H. Friedman, "Sun and earth, sustainable earth," 1986.

[28] P. Nikita, V. Kevin, and H. Mateo, Electromagnetic Radiation, Chemistry LibreTexts, California, USA, 2015.

[29] C. D'Souza, H.-G. Yuk, G. H. Khoo, and W. Zhou, "Application of light-emitting diodes in food production, postharvest preservation, and microbiological food safety," Comprehensive Reviews in Food Science and Food Safety, vol. 14, no. 6, pp. 719-740, 2015.

[30] R.-D. Jeong, E.-H. Chu, G. W. Lee, C. Cho, and H.-J. Park, "Inhibitory effect of gamma irradiation and its application for control of postharvest green mold decay of Satsuma mandarins," International Journal of Food Microbiology, vol. 234, pp. 1-8, 2016.

[31] S. C. Bhatla and M. A. Lal, Plant Physiology, Development and Metabolism, Springer, Berlin, Germany, 2018.

[32] C. H. Foyer, M. Lelandais, and K. J. Kunert, "Photooxidative stress in plants," Physiologia Plantarum, vol. 92, no. 4, pp. 696-717, 1994.

[33] V. F. Favaretto, C. A. Martinez, H. H. Soriani, and R. P. M. Furriel, "Differential responses of antioxidant enzymes in pioneer and late-successional tropical tree species grown under sun and shade conditions," Environmental and Experimental Botany, vol. 70, no. 1, pp. 20-28, 2011.

[34] J. Santini, J. Giannettini, S. Herbette et al., "Physiological and biochemical response to photooxidative stress of the fundamental citrus species," Scientia Horticulturae, vol. 147, pp. 126-135, 2012.

[35] P. Jeandet, C. Hébrard, M.-A. Deville et al., "Deciphering the role of phytoalexins in plant-microorganism interactions and human health," Molecules, vol. 19, no. 11, pp. 18033-18056, 2014.

[36] I. Ahuja, R. Kissen, and A. M. Bones, "Phytoalexins in defense against pathogens," Trends in Plant Science, vol. 17, no. 2, pp. 73-90, 2012.

[37] R. Barkai-Golan and P. A. Follett, Irradiation for Quality Improvement, Microbial Safety and Phytosanitation of Fresh Produce, Academic Press, Cambridge, MA, USA, 2017.

[38] R. L. Arruda, A. T. S. Paz, M. T. F. Bara, M. V. D. C. B. Côrtes, M. C. C. D. Filippi, and E. C. D. Conceição, "An approach on phytoalexins: function, characterization and biosynthesis in plants of the family Poaceae," Ciência Rural, vol. 46, no. 7, pp. 1206-1216, 2016.

[39] G. K. Bizuneh, "The chemical diversity and biological activities of phytoalexins," Advances in Traditional Medicine, pp. 1-13, 2020.

[40] J. Riov, "6,7-dimethoxycoumarin in the peel of gamma-irradiated grapefruit," Phytochemistry, vol. 10, no. 8, pp. 1923-1924, 1971.

[41] E. S. El-Sayed, A. M. El-Ashmawy, A. M. Galal, and I. A. Hasan, "Combined effect of gamma irradiation and thiabendozole treatment on scoparone accumulation and rot caused by Penicillium italicum and Aspergillus flavus in grapefruit," Egyptian Journal of Microbiology, vol. 36, no. 4, pp. 389-404, 2001.

[42] I. A. Dubery, A. E. Louw, and F. R. V. Heerden, "Synthesis and evaluation of 4-(3-methyl-2-butenoxy) isonitrosoacetophenone, a radiation-induced stress metabolite in citrus," Phytochemistry, vol. 50, no. 6, pp. 983-989, 1999.

[43] U. Fda, "Irradiation in the production, processing and handling of food. 21 CFR, Part 179," Federal Register, vol. 65, pp. 71056-71058, 2000.

[44] V. E. Ruiz, L. Cerioni, I. C. Zampini et al., "UV-B radiation on lemons enhances antifungal activity of flavedo extracts against Penicillium digitatum," LWT-Food Science and Technology, vol. 85, pp. 96-103, 2017.

[45] V. Rodov, S. Ben-Yehoshua, J. J. Kim, B. Shapiro, and Y. Ittah, "Ultraviolet illumination induces scoparone production in kumquat and orange fruit and improves decay resistance," Journal of the American Society for Horticultural Science, vol. 117, no. 5, pp. 788-792, 1992.

[46] M. C. Arcas, J. M. Botía, A. M. Ortuño, and J. A. D. Río, “UV irradiation alters the levels of flavonoids involved in the defence mechanism of Citrus aurantium fruits against Penicillium digitatum," European Journal of Plant Pathology, vol. 106, pp. 617-622, 2000.

[47] G. D'hallewin, M. Schirra, M. Pala, and S. Ben-Yehoshua, "Ultraviolet C irradiation at $0.5 \mathrm{~kJ} \cdot \mathrm{m}-2$ reduces decay without causing damage or affecting postharvest quality of star ruby grapefruit (C. Paradisi macf.)," Journal of Agricultural and Food Chemistry, vol. 48, no. 10, pp. 4571-4575, 2000.

[48] G. T. Gündüz and F. Pazir, "Inactivation of Penicillium digitatum and Penicillium italicum under in vitro and in vivo conditions by using UV-C light," Journal of Food Protection, vol. 76, no. 10, pp. 1761-1766, 2013.

[49] G. T. Gündüz, V. K. Juneja, and F. Pazır, "Application of ultraviolet-C light on oranges for the inactivation of postharvest wound pathogens," Food Control, vol. 57, pp. 9-13, 2015.

[50] Y. J. Fernandez and D. J. Hall, "In vitro response of Penicillium digitatum and Geotrichum candidum to ultraviolet (UV-C) exposure," Proceedings of Florida State Horticultural Society, vol. 117, pp. 380-381, 2004.

[51] R. Porat, A. Lers, S. Dori et al., "Induction of chitinase and $\beta$-1, 3-endoglucanase proteins by UV irradiation and wounding in grapefruit peel tissue," Phytoparasitica, vol. 27, no. 3, pp. 233-238, 1999.

[52] C. Stevens, C. L. Wilson, J. Y. Lu et al., "Plant hormesis induced by ultraviolet light-C for controlling postharvest diseases of tree fruits," Crop Protection, vol. 15, no. 2, pp. 129-134, 1996.

[53] C. Stevens, V. A. Khan, J. Y. Lu et al., "Integration of ultraviolet (UV-C) light with yeast treatment for control of 
postharvest storage rots of fruits and vegetables," Biological Control, vol. 10, no. 2, pp. 98-103, 1997.

[54] C. Stevens, V. A. Khan, C. L. Wilson, J. Y. Lu, E. Chalutz, and S. Droby, "The effect of fruit orientation of postharvest commodities following low dose ultraviolet light-C treatment on host induced resistance to decay," Crop Protection, vol. 24, no. 8, pp. 756-759, 2005.

[55] V. Trivittayasil, K. Nashiro, F. Tanaka, D. Hamanaka, and T. Uchino, "Inactivation characteristics and modeling of mold spores by UV-C radiation based on irradiation dose," Food Science and Technology Research, vol. 21, no. 3, pp. 365-370, 2015.

[56] K. Papoutsis, Q. Vuong, P. Pristijono et al., "Enhancing the total phenolic content and antioxidants of lemon pomace aqueous extracts by applying UV-C irradiation to the dried powder," Foods, vol. 5, no. 4, p. 55, 2016.

[57] R. Velasco, A. Zharkikh, J. Affourtit et al., "The genome of the domesticated apple (malus $\times$ domestica borkh.)," Nature Genetics, vol. 42, no. 10, pp. 833-839, 2010.

[58] I. Verde, A. G. Abbott, S. Scalabrin et al., "The high-quality draft genome of peach (Prunus persica) identifies unique patterns of genetic diversity, domestication and genome evolution," Nature Genetics, vol. 45, no. 5, pp. 487-494, 2013.

[59] K. Petroni and C. Tonelli, "Recent advances on the regulation of anthocyanin synthesis in reproductive organs," Plant Science, vol. 181, no. 3, pp. 219-229, 2011.

[60] L. Jaakola, "New insights into the regulation of anthocyanin biosynthesis in fruits," Trends in Plant Science, vol. 18, no. 9, pp. 477-483, 2013.

[61] A. Azuma, H. Yakushiji, Y. Koshita, and S. Kobayashi, "Flavonoid biosynthesis-related genes in grape skin are differentially regulated by temperature and light conditions," Planta, vol. 236, no. 4, pp. 1067-1080, 2012.

[62] F. Feng, M. Li, F. Ma, and L. Cheng, "Phenylpropanoid metabolites and expression of key genes involved in anthocyanin biosynthesis in the shaded peel of apple fruit in response to sun exposure," Plant Physiology and Biochemistry, vol. 69, pp. 54-61, 2013.

[63] K. Miyawaki, S. Fukuoka, Y. Kadomura et al., "Establishment of a novel system to elucidate the mechanisms underlying light-induced ripening of strawberry fruit with an Agrobacterium-mediated RNAi technique," Plant Biotechnology, vol. 29, no. 3, pp. 271-277, 2012.

[64] B. Lai, X.-J. Li, B. Hu et al., "LcMYB1 is a key determinant of differential anthocyanin accumulation among genotypes, tissues, developmental phases and ABA and light stimuli in Litchi chinensis," PLoS One, vol. 9, no. 1, Article ID e86293, 2014.

[65] H. G. Kim, G.-S. Kim, J. H. Lee et al., "Determination of the change of flavonoid components as the defence materials of Citrus unshiu Marc. fruit peel against Penicillium digitatum by liquid chromatography coupled with tandem mass spectrometry," Food Chemistry, vol. 128, no. 1, pp. 49-54, 2011.

[66] S. Kaewsuksaeng, Y. Urano, S. Aiamla-Or, M. Shigyo, and N. Yamauchi, "Effect of UV-B irradiation on chlorophylldegrading enzyme activities and postharvest quality in stored lime (Citrus latifolia Tan.) fruit," Postharvest Biology and Technology, vol. 61, no. 2-3, pp. 124-130, 2011.

[67] V. E. Ruiz, R. Interdonato, L. Cerioni et al., "Short-term UV$\mathrm{B}$ exposure induces metabolic and anatomical changes in peel of harvested lemons contributing in fruit protection against green mold," Journal of Photochemistry and Photobiology B: Biology, vol. 159, pp. 59-65, 2016.
[68] I. Yamaga, T. Kuniga, S. Aoki, M. Kato, and Y. Kobayashi, "Effect of ultraviolet-B irradiation on disease development caused by Penicillium italicum in satsuma Mandarin fruit," The Horticulture Journal, vol. 85, no. 1, pp. 86-91, 2015.

[69] R. Interdonato, M. Rosa, C. B. Nieva, J. A. González, M. Hilal, and F. E. Prado, "Effects of low UV-B doses on the accumulation of UV-B absorbing compounds and total phenolics and carbohydrate metabolism in the peel of harvested lemons," Environmental and Experimental Botany, vol. 70, no. 2-3, pp. 204-211, 2011.

[70] A. Asthana and R. W. Tuveson, "Effects of UV and phototoxins on selected fungal pathogens of citrus," International Journal of Plant Sciences, vol. 153, no. 3, pp. 442-452, 1992.

[71] G. M. Olmedo, L. Cerioni, M. M. González, F. M. Cabrerizo, S. I. Volentini, and V. A. Rapisarda, "UVA photoactivation of harmol enhances its antifungal activity against the phytopathogens Penicillium digitatum and Botrytis cinerea," Frontiers in Microbiology, vol. 8, p. 347, 2017.

[72] G. M. Olmedo, L. Cerioni, M. M. González, F. M. Cabrerizo, V. A. Rapisarda, and S. I. Volentini, "Antifungal activity of $\beta$-carbolines on Penicillium digitatum and Botrytis cinerea," Food Microbiology, vol. 62, pp. 9-14, 2017.

[73] M. T. Lafuente and F. Alférez, "Effect of LED blue light on Penicillium digitatum and Penicillium italicum strains," Photochemistry and Photobiology, vol. 91, no. 6, pp. 14121421, 2015.

[74] F. Alferez, H.-L. Liao, and J. K. Burns, "Blue light alters infection by Penicillium digitatum in tangerines," Postharvest Biology and Technology, vol. 63, no. 1, pp. 11-15, 2012.

[75] A.-R. Ballester and M. T. Lafuente, "LED Blue Light-induced changes in phenolics and ethylene in citrus fruit: implication in elicited resistance against Penicillium digitatum infection," Food Chemistry, vol. 218, pp. 575-583, 2017.

[76] I. Yamaga, T. Takahashi, K. Ishii, M. Kato, and Y. Kobayashi, "Suppression of blue mold symptom development in satsuma Mandarin fruits treated by low-intensity blue LED irradiation," Food Science and Technology Research, vol. 21, no. 3, pp. 347-351, 2015.

[77] I. Yamaga and S. Nakamura, "Blue LED irradiation induces scoparone production in wounded satsuma Mandarin "aoshima unshu" and reduces fruit decay during long-term storage," The Horticulture Journal, vol. 87, no. 4, pp. 474480, 2018.

[78] H.-L. Liao, F. Alferez, and J. K. Burns, "Assessment of blue light treatments on citrus postharvest diseases," Postharvest Biology and Technology, vol. 81, pp. 81-88, 2013.

[79] J. M. Christie, "Phototropin blue-light receptors," Annual Review of Plant Biology, vol. 58, no. 1, pp. 21-45, 2007.

[80] T. E. Bramanti and S. C. Holt, "Roles of porphyrins and host iron transport proteins in regulation of growth of Porphyromonas gingivalis W50," Journal of Nacteriology, vol. 173, no. 22, pp. 7330-7339, 1991.

[81] I. Yamaga, T. Takahashi, K. Ishii, M. Kato, and Y. Kobayashi, "Antifungal effect of blue LED irradiation on the blue mold, Penicillium italicum, in satsuma Mandarin fruits," Horticultural Research (Japan), vol. 14, no. 1, pp. 83-87, 2015.

[82] H.-L. Liao and J. K. Burns, "Light controls phospholipase $\mathrm{A}_{2} \alpha$ and $\beta$ gene expression in Citrus sinensis," Journal of Experimental Botany, vol. 61, no. 9, pp. 2469-2478, 2010.

[83] N. Sharma and A. Tripathi, "Effects of Citrus sinensis (L.) osbeck epicarp essential oil on growth and morphogenesis of Aspergillus niger (L.) van tieghem," Microbiological Research, vol. 163, no. 3, pp. 337-344, 2008. 
[84] L. Shi, S. Cao, W. Chen, and Z. Yang, "Blue light induced anthocyanin accumulation and expression of associated genes in Chinese bayberry fruit," Scientia Horticulturae, vol. 179, pp. 98-102, 2014.

[85] İ. Kahramanoğlu and S. Usanmaz, "Improving postharvest storage quality of cucumber fruit by modified atmosphere packaging and biomaterials," HortScience, vol. 54, no. 11, pp. 2005-2014, 2019.

[86] A. J. D. Lucca, C. Carter-Wientjes, K. A. Williams, and D. Bhatnagar, "Blue light $(470 \mathrm{~nm})$ effectively inhibits bacterial and fungal growth," Letters in Applied Microbiology, vol. 55, no. 6, pp. 460-466, 2012.

[87] T. Dai, A. Gupta, C. K. Murray, M. S. Vrahas, G. P. Tegos, and M. R. Hamblin, "Blue light for infectious diseases: propionibacterium acnes, Helicobacter pylori, and beyond?" Drug Resistance Updates, vol. 15, no. 4, pp. 223-236, 2012.

[88] C. Rojas-Argudo, L. Palou, A. Bermejo, A. Cano, M. A. D. Río, and M. C. González-Mas, "Effect of X-ray irradiation on nutritional and antifungal bioactive compounds of "Clemenules" clementine mandarins," Postharvest Biology and Technology, vol. 68, pp. 47-53, 2012.

[89] L. Palou, A. Marcilla, C. Rojas-Argudo, M. Alonso, J.-A. Jacas, and M. A. D. Río, "Effects of X-ray irradiation and sodium carbonate treatments on postharvest Penicillium decay and quality attributes of clementine mandarins," Postharvest Biology and Technology, vol. 46, no. 3, pp. 252261, 2007.

[90] M. Alonso, L. Palou, M. Á. D. Río, and J.-A. Jacas, "Effect of $\mathrm{X}$-ray irradiation on fruit quality of clementine Mandarin cv. "Clemenules"," Radiation Physics and Chemistry, vol. 76, no. 10, pp. 1631-1635, 2007.

[91] S. R. Moosekian, S. Jeong, B. P. Marks, and E. T. Ryser, "Xray irradiation as a microbial intervention strategy for food," Annual Review of Food Science and Technology, vol. 3, no. 1, pp. 493-510, 2012.

[92] H. Oufedjikh, M. Mahrouz, M. J. Amiot, and M. Lacroix, "Effect of $\gamma$-irradiation on phenolic compounds and phenylalanine ammonia-lyase activity during storage in relation to peel injury from peel of Citrus clementina Hort. Ex. Tanaka," Journal of Agricultural and Food Chemistry, vol. 48, no. 2, pp. 559-565, 2000.

[93] W. Droge, "Free radicals in the physiological control of cell function," Physiological Reviews, vol. 82, no. 1, pp. 47-95, 2002.

[94] C. Wang, Y. Gao, Y. Tao, X. Wu, and C. Zhibo, "Influence of $\gamma$-irradiation on the reactive-oxygen metabolism of blueberry fruit during cold storage," Innovative Food Science \& Emerging Technologies, vol. 41, pp. 397-403, 2017.

[95] P. Cia, S. F. Pascholati, E. A. Benato, E. C. Camili, and C. A. Santos, "Effects of gamma and UV-C irradiation on the postharvest control of papaya anthracnose," Postharvest Biology and Technology, vol. 43, no. 3, pp. 366-373, 2007.

[96] A. P. K. Ling, J. Y. Chia, S. Hussein, and A. R. Harun, "Physiological responses of Citrus sinensis to gamma irradiation," World Applied Science, vol. 5, pp. 12-19, 2008.

[97] G. A. Mahmoud, K. M. K. El-Tobgy, and M. Abo-El-Seoud, "Application of combined biocides and gamma radiation for keeping good quality stored grapefruits," Archives of Phytopathology and Plant Protection, vol. 43, no. 7, pp. 712-721, 2010.

[98] K. B. Adams, M. T. Wu, and D. K. Salunkhe, "Effects of gamma radiation on growth and patulin production of Penicillium expansum and Penicillium patulim,"
Environmental and Experimental Botany, vol. 16, no. 2-3, pp. 189-193, 1976.

[99] C. Zhu, M. Lei, M. Andargie, J. Zeng, and J. Li, “Antifungal activity and mechanism of action of tannic acid against Penicillium digitatum," Physiological and Molecular Plant Pathology, vol. 107, pp. 46-50, 2019.

[100] S. J. Dixon, K. M. Lemberg, M. R. Lamprecht et al., "Ferroptosis: an iron-dependent form of nonapoptotic cell death," Cell, vol. 149, no. 5, pp. 1060-1072, 2012.

[101] B. R. Stockwell, J. P. F. Angeli, H. Bayir et al., "Ferroptosis: a regulated cell death nexus linking metabolism, redox biology, and disease," Cell, vol. 171, no. 2, pp. 273-285, 2017.

[102] S. Dangol, Y. Chen, B. K. Hwang, and N.-S. Jwa, "Iron-and reactive oxygen species-dependent ferroptotic cell death in rice-Magnaporthe oryzae interactions," The Plant Cell, vol. 31, no. 1, pp. 189-209, 2019.

[103] C. Caseys, "Ferroptosis: a companion of ROS in fighting Magnaporthe in rice," The Plant Cell, vol. 31, no. 1, pp. 13-14, 2019.

[104] W. S. Yang and B. R. Stockwell, "Ferroptosis: death by lipid peroxidation," Trends in Cell Biology, vol. 26, no. 3, pp. 165-176, 2016.

[105] L. Galluzzi, I. Vitale, S. A. Aaronson et al., "Molecular mechanisms of cell death: recommendations of the nomenclature committee on cell death 2018," Cell Death and Differentiation, vol. 25, pp. 486-541, 2018.

[106] J. Y. Cao and S. J. Dixon, "Mechanisms of ferroptosis," Cellular and Molecular Life Sciences, vol. 73, no. 11-12, pp. 2195-2209, 2016.

[107] A. Linkermann, B. R. Stockwell, S. Krautwald, and H.-J. Anders, "Regulated cell death and inflammation: an auto-amplification loop causes organ failure," Nature Reviews Immunology, vol. 14, no. 11, pp. 759-767, 2014.

[108] H. Z. Feng and B. R. Stockwell, "Unsolved mysteries: how does lipid peroxidation cause ferroptosis?" PLoS Biology, vol. 16, no. 5, Article ID e2006203, 2018.

[109] J. E. Cassat and E. P. Skaar, "Iron in infection and immunity," Cell Host \& Microbe, vol. 13, no. 5, pp. 509-519, 2013.

[110] R. Singh, S. Dangol, Y. Chen et al., "Magnaporthe oryzae effector AVR-Pii helps to establish compatibility by inhibition of the rice NADP-malic enzyme resulting in disruption of oxidative burst and host innate immunity," Molecules and Cells, vol. 39, no. 5, pp. 426-438, 2016.

[111] G. Liu, D. L. Greenshields, R. Sammynaiken, R. N. Hirji, G. Selvaraj, and Y. Wei, "Targeted alterations in iron homeostasis underlie plant defense responses," Journal of Cell Science, vol. 120, no. 4, pp. 596-605, 2007.

[112] R. Skouta, S. J. Dixon, J. Wang et al., "Ferrostatins inhibit oxidative lipid damage and cell death in diverse disease models," Journal of the American Chemical Society, vol. 136, no. 12, pp. 4551-4556, 2014.

[113] R. J. Clem, "Viral IAPs, then and now," Seminars in Cell \& Developmental Biology, vol. 39, pp. 72-79, 2015. 